Max-Planck-Institut für demografische Forschung

Max Planck Institute for Demographic Research

Konrad-Zuse-Strasse 1 - D-18057 Rostock = Germany = Tel +49 (0) 3812081 - 0 - Fax +49 (0) 3812081 - 202 - www.demogr.mpg.de

MPIDR Working Paper WP 2019-022 I October 2019

\title{
Assessing the quality of self-reported education in Brazil with intercensal survivorship ratios
}

Marília R. Nepomuceno I nepomuceno@demogr.mpg.de Cássio M. Turra

\footnotetext{
This working paper has been approved for release by: Alyson van Raalte (vanRaalte@demogr.mpg.de), Head of the Research Group:Lifespan Inequalities.

(C) Copyright is held by the authors.

Working papers of the Max Planck Institute for Demographic Research receive only limited review. Views or opinions expressed in working papers are attributable to the authors and do not necessarily reflect those of the Institute.
} 


\title{
Assessing the quality of self-reported education in Brazil with intercensal survivorship ratios
}

\author{
Marília R. Nepomuceno*1 and Cássio M. Turra ${ }^{2}$ \\ ${ }^{1}$ Max Planck Institute for Demographic Research, Rostock, Germany \\ ${ }^{2}$ Centre for Development and Regional Planning - CEDEPLAR - Federal University of Minas Gerais, \\ Belo Horizonte, Brazil
}

\begin{abstract}
In developing countries, improving access to schooling has been and remains a priority. At the same time, a growing body of research relates education to demographic variables. It is therefore essential to measure the education variable accurately. In Brazil, although the high degree of inaccuracy in age reporting is well known, previous research has neglected problems of misreporting which may affect other variables such as education. To fill this gap, we calculate mortality levels by education as implied by intercensal survivorship ratios, to investigate the quality of self-reported education among adults in Brazil between the 1991 and 2000 censuses. Our findings show evidence of education misreporting. Analysis by single year of schooling only barely revels the expected educational gradient in mortality. After categorization of age and years of schooling into groups, a positive relationship between education and survival does appear, although some implausible patterns remain. This study is an important step in demonstrating and assessing potential errors in census education data in Brazil. Our results highlight the importance of efforts to reduce misreporting of data on education, particularly in countries where an educational expansion is underway, and deficiencies in data quality are a potential issue of concern.
\end{abstract}

Keywords: Census data; education misreporting; data quality; developing countries; Brazil; adult mortality.

\footnotetext{
${ }^{*}$ Corresponding author. E-mail: nepomuceno@demogr.mpg.de
} 


\section{Introduction}

Education is one of the keys to development and economic growth and is connected to demographic variables in many different ways. In virtually all societies, individuals with higher levels of education enjoy better health and longer lives (Preston and Taubman 1994; Elo and Preston 1996; Mackenbach et al. 1999; Koch et al. 2007; Zhu and Xie 2007; Rosero-Bixby and Dow 2009; Turra et al. 2016; Lutz and Kebede 2018; Smith-Greenaway and Yeatman 2019). Highly educated couples have fewer children, mainly because they marry later, use contraception more effectively, and have more autonomy in reproductive decision-making (Singh and Casterline 1985; Potter et al. 2010; Bongaarts et al. 2017; Rios-Neto et al. 2018). Moreover, migration flows across regions with different developmental levels are usually associated with selection of migrants by education group (de Haas 2010; Lewis 1986). It is thus not surprising that as educational enrolments expand worldwide, there is a growing emphasis on population forecasts by educational level (KC et al. 2010; Lutz and KC 2011; Lutz et al. 2014).

As an essential variable in demographic analysis, accurate measurement of education is indispensable. Studies of the quality of reported education are not new in the literature (Folger and Nam 1964; Gustavus and Nam 1968; Black et al. 2003; Sorlie and Johnson 1996; Kane et al. 1999; Johnson-Greene et al. 1997; Battistin et al. 2014; Lerch et al. 2017). Some of these have documented the misreporting of educational levels in data systems. For example, in both the 1950 and 1960 U.S. census, there was a significant amount of net overreporting, particularly at older ages for high school and college levels (Folger and Nam 1964). Examination of the 1990 U.S. census detected misreporting of some doctoral and professional degree categories (Black et al. 2003).

One of the consequences of education misreporting in census data is the miscalculation of the denominator of demographic rates, which can bias the measurement of educational gradients. In mortality analysis, for example, where death rates usually derive from two independent data sources - vital statistics (death counts) and census data (exposures-at-risk) - disagreement between reported education in the numerator and denominator may affect conclusions about how mortality differentials by education vary across age, gender, race, and geographical groups. Several authors have documented disagreements between death counts and population census records by education in Europe and the U.S.. The level of disagreement tends to increase with age in Lithuania (Shkolnikov et al. 2007), and for some racial/ethnic groups in the U.S. such as blacks and Hispanics (Rostron et al. 2010). However, even among population groups that 
are less likely to report education levels differently across data sources, changes in the census questions can lead to inconsistent information over time (Lerch et al. 2017).

In Brazil, research has neglected the possible effects of education misreporting in demographic, social, and economic studies. Although several authors have looked at coverage errors, both in vital and census data (Paes and Albuquerque 1999; Paes 2007; Lima and Queiroz 2014; Cavenaghi and Alves 2016), demographers have paid less attention to content errors, and analysis has mostly been limited to age misreporting (e.g. Paes and Albuquerque 1999; Agostinho 2009; Gomes and Turra 2009; Turra 2012; di Lego et al. 2017; Nepomuceno and Turra 2019). Nevertheless, the high degree of inaccuracy in age reporting suggests that problems of misreporting may affect other variables, including education.

This article examines the quality of education information in Brazilian census data. To do this, we calculate mortality levels by education as implied by intercensal survivorship ratios, to investigate the quality of self-reported education data among adults in Brazil between the 1991 and 2000 censuses. Here, we hypothesize that measurement errors are more substantial during times of accelerated expansion of schooling, such as the period that characterized the education system in Brazil after 1980 (IBGE 2004; Rios-Neto et al. 2010). The rapid education transition may have influenced the reliability of education data in at least three different ways. First, if better-educated individuals tend to report their characteristics more accurately, mainly when information is retrospective, errors will be more substantial in earlier data collections and among older cohorts. Second, the expansion of education may have changed people's perception of their relative social position. Older age groups, who lived their schooling years before the development of the education system, may feel inclined to overstate their educational levels to level-off any cohort differences. Finally, the expansion of schooling has been followed by changes in the educational system and census questions, affecting the comparability of responses over time. Given the global effort to improve access to schooling (United Nations 2015, 2016), our results aim to draw attention to the accuracy of reported education not only in Brazil but also in those countries where educational expansion is underway, and deficient data quality is a potential issue. 


\section{Data and Methods}

We drew data for men and women 40-89 years old, from the 1991 and 2000 Brazilian Census (IPUMS-I 2019). Although the most recent census data available are from 2010, the exclusion from the questionnaire of information on the highest grade completed precluded us from using the data for that year. To have an exact 10-year interval between periods, we estimated the population for the year 1990 based on the set of age-specific growth rates between 1991 and 2000 and the population in 1991. We selected only individuals who were not attending school at the census time, representing about $99.5 \%$ of the population aged 40 to 89 in 1990 and $97.3 \%$ in 2000 .

We measure educational attainment as the highest grade completed within the most advanced level attended in the education system. We used the IPUMS' harmonized variable named "YRSCHOOL" which accounts for the number of years of schooling.

To evaluate the quality of self-reported education, we assessed the implicit mortality by education between the two censuses through intercensal survivorship ratios (ISR) by age, sex, and educational attainment:

$$
\operatorname{ISR}_{x}^{k, i}(j)=\frac{N_{x+j}^{k, i}(t+j)}{N_{x}^{k, i}(t)}
$$

where $N_{x}^{k, i}(t)$ is the cohort at age $x$, sex $k$, at educational level $i$ in the year $t$, and $N_{x+j}^{k, i}(t+j)$ is the same cohort $j$ years older at the educational level $i$ and sex $k$ in the year $t+j$. In our first analysis, we used single year of schooling, from 0 to $12+$. Next, we calculated the number of years of schooling categorized into four intervals: $0-3,4-8,9-11$, and $12+$, that correspond respectively to the first and second stages of the primary, secondary and tertiary education.

After the categorization of the years of schooling, values of the ISR at each age were translated into life expectancy at age 40 in the Coale-Demeny West model life-table (Coale et al. 1983). We used the United Nations version of the Coale-Demeny Model Life Tables, which extends the original mortality levels to include life expectancy at birth up to 100 years (United Nations 2017). This allowed us to assess the consistency of the adult level of mortality across age and educational groups. 
The ISR capture changes in the cohort size during the intercensal period. In the absence of international migration and changes in census data quality, one should expect survivorship ratios to be less than one due to the impact of mortality. Here we assume that the population was closed to international migration at ages above 40, between 1990 and 2000. This assumption is reasonable because the international net migration rate was very low during the 1990s in Brazil, reaching less than half of one percent for the population aged ten years and older (Carvalho and Campos 2006; Campos 2011), and an even lower values at older ages (Garcia 2013). To mitigate the effect of changes in census coverage on the ISR, we also adjusted the census enumeration according to omission rates (1.04 and 1.02, respectively for males and females for 1990, and 1.03 for males and 1.01 for females in 2000) published by the Brazilian Institute of Geography and Statistics (IBGE 2003).

We expect survivorship ratios to increase with educational attainment. Earlier analyses that used surveys or data from the Mortality Information System of the Ministry of Health suggested a strong educational gradient in adult mortality in Brazil (Rentería and Turra 2009; Turra et al. 2016, 2018). Despite the existence of public programs to improve or supplement adult education, we expect only negligible gains in education over time, at ages above 40 in Brazil. Between the 1991 and 2000 censuses, the proportion of individuals who reported not attending school varied from $99.2 \%$ to $96.5 \%$ for the age group $40-49$, and from $99.6 \%$ to $98.2 \%$ for the age group $50-59$. For older age groups, these proportions were even higher and more similar in the two censuses: between $99.7 \%$ and $99 \%$ for the age group $60-69,99.8 \%$ to $99.3 \%$ for the age group $70-79$, and $99.8 \%$ and $99.4 \%$ for individuals aged 80 and older.

\section{Results}

Table 1 presents the education distribution by age groups and sex in Brazil. In both years, there is a substantial proportion of adults in the least educated groups, and a smaller percentage in the most educated categories. Between 1990 and 2000, the most considerable change in the education distribution is among the least educated (0-3 years of schooling), mainly for younger age groups because of the advance of the education transition in the country. For older age groups, proportions change only slightly over time. 


\begin{tabular}{|c|c|c|c|c|c|c|c|c|}
\hline \multirow{3}{*}{$\begin{array}{l}\text { Age } \\
\text { Group }\end{array}$} & \multicolumn{8}{|c|}{ Years of schooling } \\
\hline & \multicolumn{2}{|c|}{$0-3$} & \multicolumn{2}{|c|}{$4-8$} & \multicolumn{2}{|c|}{$9-11$} & \multicolumn{2}{|c|}{$12+$} \\
\hline & 1990 & 2000 & 1990 & 2000 & 1990 & 2000 & 1990 & 2000 \\
\hline & \multicolumn{8}{|c|}{ Men } \\
\hline $40-49$ & 42.95 & 29.35 & 38.39 & 42.83 & 9.71 & 16.95 & 8.95 & 10.87 \\
\hline $50-59$ & 52.43 & 41.69 & 34.78 & 38.13 & 6.80 & 10.73 & 5.98 & 9.45 \\
\hline $60-69$ & 61.40 & 53.25 & 29.34 & 33.33 & 4.76 & 7.29 & 4.51 & 6.13 \\
\hline $70-79$ & 69.86 & 61.95 & 23.50 & 27.90 & 3.09 & 5.18 & 3.55 & 4.97 \\
\hline \multirow[t]{2}{*}{$80-89$} & 73.98 & 69.87 & 20.45 & 22.85 & 2.55 & 3.40 & 3.03 & 3.88 \\
\hline & \multicolumn{8}{|c|}{ Women } \\
\hline $40-49$ & $\overline{46.05}$ & 29.12 & 36.40 & 41.59 & 10.31 & 18.11 & 7.24 & 11.18 \\
\hline $50-59$ & 57.30 & 44.67 & 32.49 & 36.55 & 6.55 & 11.07 & 3.66 & 7.71 \\
\hline $60-69$ & 65.01 & 56.56 & 28.14 & 32.55 & 4.79 & 7.06 & 2.06 & 3.84 \\
\hline $70-79$ & 71.10 & 62.41 & 23.59 & 29.48 & 4.13 & 5.76 & 1.18 & 2.34 \\
\hline $80-89$ & 74.09 & 68.32 & 21.71 & 25.18 & 3.40 & 5.11 & 0.80 & 1.40 \\
\hline
\end{tabular}

Table 1: Education distribution (\%) by age: Brazil, men and women 1990 and 2000. Source: Census data (IPUMS-I 2019).

Figure 1 shows intercensal survivorship ratios by age, sex, and single year of schooling. The estimates show an irregular and unexpected pattern of the ISR by education. First, except for the oldest cohorts (70-74 and 75-79 years old in 1990), the ISR can get higher than one, suggesting that the size of cohorts increased between the censuses for some years of completed schooling, despite the impact of mortality. Second, the ISR do not increase monotonically with education. Although survivorship tends to increase at higher years of schooling, it fluctuates over the distribution, varying sharply, particularly at one, five and nine years of schooling. For example, the number of men and women aged 40-44 with one year of schooling increased by more than $30 \%$ between 1990 and 2000, and more than $40 \%$ for those with five years of schooling. For nine years of schooling, the number of women and men aged 55-59 reporting this level increased by $30 \%$ and 10\% respectively between 1990 and 2000 . 

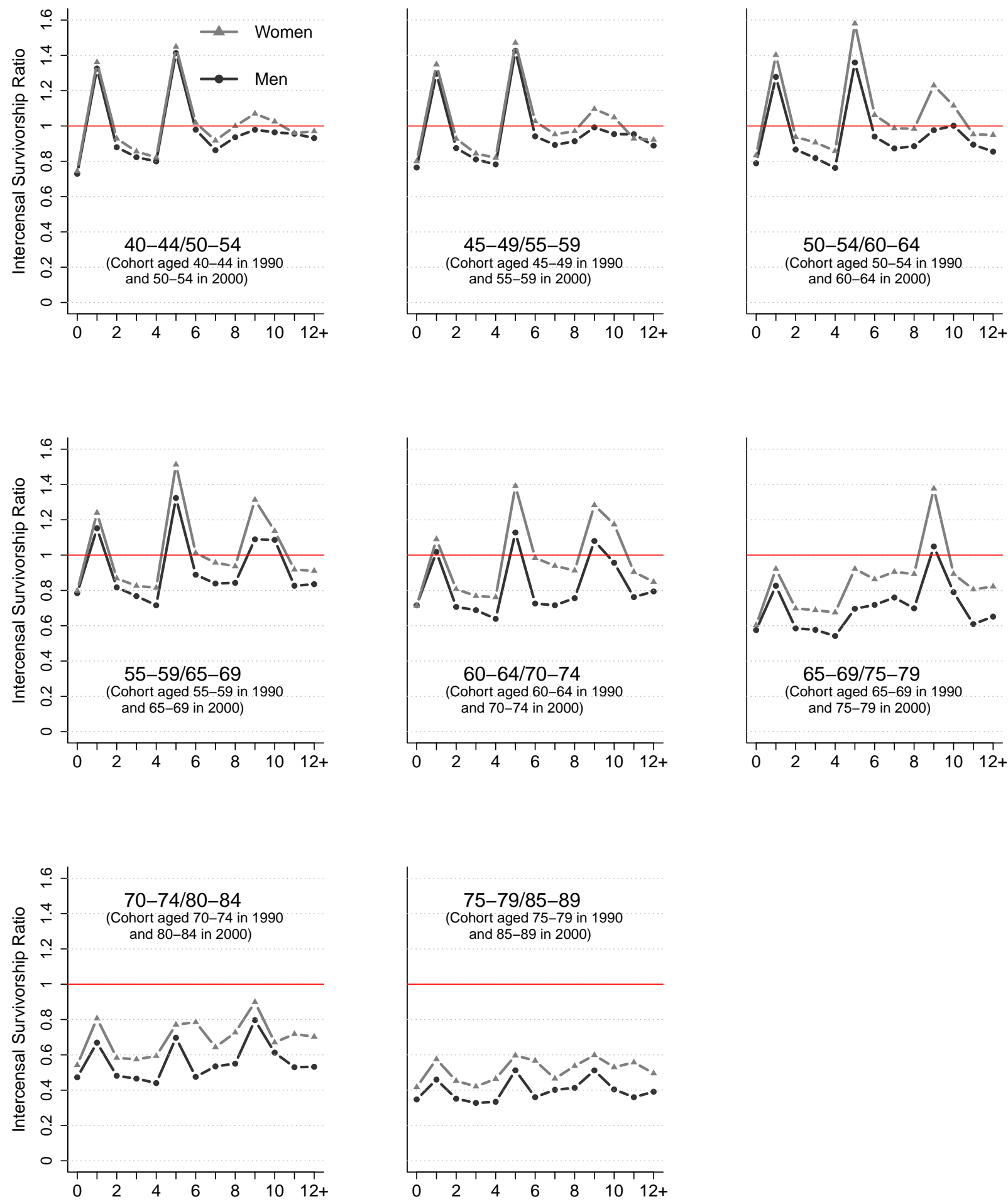

Years of Schooling

Figure 1: Intercensal Survivorship Ratio by age and years of schooling: Brazil, men and women, 1990-2000.

Source: Census data (IPUMS-I 2019). 
One way to re-examine education reporting is by categorizing years of schooling into intervals (0-3, 4-8, 9-11, and 12+). Table 2 shows the results, including the ISR and the life expectancy at age $40\left(e_{40}\right)$ from the West Model of the Coale-Demeny Life Tables implied by the ISR. To further improve our estimates, we also re-categorized the 5-year into 10-year age intervals, hoping to minimize the possible effects of age misreporting in the census, particularly at older ages (Agostinho 2009; Nepomuceno and Turra 2019).

Table 2 shows the educational gradient in mortality, i.e., the positive relationship between education and survival. Life expectancy at age 40 is 0.44 to 7.84 years lower for individuals with 0-3 years of schooling than for those with 12 or more years of schooling, depending on the cohort and sex.

Some implausible results remain after the categorization of years of schooling. Table 2 reveals that the survival advantage of the most educated does not decrease monotonically with age. For instance, the difference in $e_{40}$ between the least and the most educated drops from 7.8 years for women aged 40-49 to 5.2 to those aged 50-59 in 1990. But it then increases to 6.1 years at the age group 60-69, reducing to 4.0 at 70-79 years in 1990. By comparing the individuals with 9-11 and those with 12 years or more of schooling, we identify other implausible results that cast doubt on the quality of self-reported education in the Brazilian census. For most male and female cohorts, life expectancy reduces for those with $12+$ years of schooling compared with 9-11 years of schooling, contradicting the expected gradient. Table 2 also shows that mortality levels implied by the ISR vary significantly across cohorts/age. For all educational categories and both sexes, the $e_{40}$ implied by the ISR increases for the older cohorts, and the difference can get as high as twelve years for the lowest educated group. 


\begin{tabular}{|c|c|c|c|c|c|c|c|c|c|}
\hline \multirow[b]{3}{*}{$\begin{array}{c}\text { Age in } \\
1990\end{array}$} & \multirow[b]{3}{*}{$\begin{array}{c}\text { Age in } \\
2000\end{array}$} & \multicolumn{6}{|c|}{ Years of schooling } & \multirow{2}{*}{\multicolumn{2}{|c|}{$12+$}} \\
\hline & & \multicolumn{2}{|c|}{$0-3$} & \multicolumn{2}{|c|}{$4-8$} & \multicolumn{2}{|c|}{$9-11$} & & \\
\hline & & $\begin{array}{c}\text { Survival } \\
\text { ratio }\end{array}$ & $\begin{array}{c}\text { Implied } \\
e_{40}\end{array}$ & $\begin{array}{c}\text { Survival } \\
\text { ratio }\end{array}$ & $\begin{array}{c}\text { Implied } \\
e_{40}\end{array}$ & $\begin{array}{c}\text { Survival } \\
\text { ratio }\end{array}$ & $\begin{array}{c}\text { Implied } \\
e_{40}\end{array}$ & $\begin{array}{c}\text { Survival } \\
\text { ratio }\end{array}$ & $\begin{array}{c}\text { Implied } \\
e_{40} \\
\end{array}$ \\
\hline & & \multicolumn{8}{|c|}{ Men } \\
\hline $40-49$ & $50-59$ & 0.8410 & 26.66 & 0.8603 & 27.94 & 0.9570 & 36.21 & 0.9145 & 31.64 \\
\hline $50-59$ & $60-69$ & 0.8398 & 33.52 & 0.7925 & 30.67 & 0.8867 & 36.79 & 0.8469 & 33.96 \\
\hline $60-69$ & $70-79$ & 0.6747 & 34.94 & 0.6358 & 33.17 & 0.7287 & 37.26 & 0.7381 & 37.56 \\
\hline \multirow[t]{2}{*}{$70-79$} & $80-89$ & 0.4350 & 37.46 & 0.4229 & 37.70 & 0.4785 & 38.46 & 0.4762 & 39.62 \\
\hline & & \multicolumn{8}{|c|}{ Women } \\
\hline $40-49$ & $50-59$ & 0.8671 & 28.51 & 0.8974 & 30.76 & 0.9600 & 37.64 & 0.9523 & 36.34 \\
\hline $50-59$ & $60-69$ & 0.8798 & 35.51 & 0.8931 & 36.49 & 0.9607 & 44.30 & 0.9344 & 40.74 \\
\hline $60-69$ & $70-79$ & 0.7090 & 35.87 & 0.7739 & 38.74 & 0.8881 & 45.15 & 0.8388 & 41.95 \\
\hline $70-79$ & $80-89$ & 0.5082 & 40.20 & 0.5646 & 42.04 & 0.6545 & 44.94 & 0.6241 & 44.20 \\
\hline
\end{tabular}

Table 2: Intercensal Survivorship Ratio by educational groups and decennial age groups: Brazil, men and women, 1990-2000.

Note:* life expectancy at age 40 from the Model West implied by the ISR.

Source: Census data (IPUMS-I 2019).

\section{Discussion and Conclusion}

Our study shows evidence of education misreporting in Brazil. The ISR by single year of schooling only barely reflects the known educational gradient in mortality described in the literature. After the categorization of the years of schooling, the positive relationship between education and survival shows up, although some implausible results remained.

An ISR higher than one, mainly at one, five and nine years of education, suggests an unlikely increase in the cohort size between censuses. In the Brazilian education system, these grades corresponded to the beginning of stages 1 and 2 of primary (1-4,5-8 years of schooling) and the beginning of secondary (9-11 years of schooling) in 1990. Therefore, the implausible high ISR at these points of the distribution suggests two possible (complementary) explanations. First, some adults may have genuinely moved between levels of educational attainment over the intercensal period, more than compensating the mortality effect. Second (and more likely), a fraction of the cohorts may have misclassified themselves as literate or having some stage 2 of primary or secondary education in the second census, because of memory error and other self-reporting inconsistencies caused by changes in the social context, the census questionnaire, and education reforms. 
The cohorts we analyzed experienced at least two education reforms after their schooling years that greatly changed the structure and the terminology of the education system, one in 1971, and another in 1996. The first reform, for instance, merged two formerly levels that corresponded, respectively, to 1-4 grades and 5-8 grades into a new level with 1-8 grades (Rigotti and Cerqueira 2004). Individuals who lived their schooling years before these reforms may have problems to classify themselves according to the new education system, resulting in misclassification of their educational level. Further, census questions to measure educational attainment changed over time, which may be another source of inconsistency. In 1991 census, the questions to calculate the highest grade completed within the most advanced level attended were "What was the last grade passed?" and "What was the last level passed"; while in 2000 the questions were "What was the highest course attended, in which you completed at least one grade?" and "What was the last grade passed?". These mentioned changes point out some challenges in the comparison of the years of schooling over time, by age and cohorts, as revealed by our findings.

Education gains may also contribute to the implausible higher ISR. Since the number of individuals aged 40-49 with one year of schooling increased by more than $30 \%$ during the intercensal period, and part of this may be due to education gains, we checked the proportion of illiterates who were attending school in the 1991 census, and could potentially achieve one year of schooling between 1991 and 2000. This proportion was very low, reaching less than $0.05 \%$ in 1991, and less than $0.06 \%$ in the 2000 census. This small proportion is not enough to explain the striking increase in the population aged 40-49 with one year of schooling between the censuses.

To minimize the effects of age and education misreporting, we presented results by 10 -year age groups and four intervals of years of schooling. After the re-categorization, the educational gradient in mortality became more explicit, and the estimated ISR were all lower than one. The categorization of the years of schooling is an alternative to reduce the effect of education misreporting. However, since there are substantial socio and economic differences among individuals within groups, by categorizing, we cannot measure important educational differences in mortality due to the inconsistencies revealed by the ISR by single years of schooling.

Our results also show some inconsistencies after the re-categorization, including lower ISR for individuals with $12+$ than $9-11$ years of schooling. One important finding is the lack of consistency in mortality levels by age. According to the $e_{40}$ implied by the ISR, older cohorts experienced lower levels of mortality at older ages. The difference is particularly strong for the least educated. The lower levels of mortality at older ages could be explained by the unusual 
adult age pattern of mortality in Brazil, which has been shown to increase with age at a slower rate than in countries with high-quality population and mortality data (Turra 2012).

Since the estimates provided here show evidence of education misreporting in the census, our findings increase concerns about the true educational distribution of the adult population. Further, since the data on education attainment seem to be differentially misreported by age and educational level, the validity of age-specific demographic rates by educational level should be interpreted cautiously in Brazil. Furthermore, if education misreporting is different across censuses, trend analysis using these data will reflect erroneous patterns. Global studies that use census education data from developing countries to project population should be aware of this weakness. Lastly, our findings draw attention to the importance of investigating the potential bias in demographic rates by educational levels in Brazil and in other developing countries where educational expansion is underway.

This study is just the first step in revealing potential errors in census education data, and we still do not know nearly enough. Efforts need to be made to measure the magnitude and the direction (overreporting and underreporting) of misreporting of census education data, for the whole population and for subgroups. Different sources of education data could be used to estimate the amount of education misreporting and provide adjusted figures. Linkage with administrative records may help, although this type of data is rarer at older ages. At the same time, attempts to reduce misreporting of education should rely on improvements in census data collection, such as in phrasing of relevant and comparable questions over time and the reduction of omission rates. 


\section{Acknowledgement}

We thank Alyson van Raalte, Ugofilippo Basellini, Simone Wajnman, Jose Alberto de Carvalho, Bernardo Queiroz, Mirian Ribeiro and Marco Gonzaga for their helpful comments and suggestions. This present study was supported by the European Research Council [grant number 716323] and by the Brazilian Graduate Studies Coordinating Board (Capes, Code 001), which funds the Demography Program at the Federal University of Minas Gerais, and the Brazilian National Research Council (CNPq). 


\section{References}

Agostinho, C. S. (2009). Estudo sobre a mortalidade adulta, para Brasil entre 1980 e 2000 e Unidades da Federação em 2000: uma aplicação dos métodos de distribuição de mortes. PhD thesis, Universidade Federal de Minas Gerais, Faculdade de Ciencias Economicas, CEDEPLAR.

Battistin, E., Nadai, M. D., and Sianesi, B. (2014). Misreported schooling, multiple measures and returns to educational qualifications. Journal of Econometrics, 181(2):136-150.

Black, D., Sanders, S., and Taylor, L. (2003). Measurement of higher education in the census and current population survey. Journal of the American Statistical Association, 98(463):545-554.

Bongaarts, J., Mensch, B. S., and Blanc, A. K. (2017). Trends in the age at reproductive transitions in the developing world: The role of education. Population Studies, 71(2):139-154.

Campos, M. B. (2011). Reversão do saldo migratório internacional negativo do brasil? evidências preliminares com base nos dados do censo 2010. Revista Paranaense de Desenvolvimento Econômico e Social, (121).

Carvalho, J. A. M. and Campos, M. B. (2006). A variação do saldo migratório internacional do brasil. Estudos Avançados, 20(57):55-58.

Cavenaghi, S. M. and Alves, J. E. D. (2016). Qualidade das informações sobre fecundidade no censo demográfico de 2010. Revista Brasileira de Estudos de População, 33(1):189-206.

Coale, A. J., Demeny, P., and Vaughan, B. (1983). Regional Model Life Tables and Stable Populations: Studies in Population. Academic Press.

de Haas, H. (2010). Migration and development: A theoretical perspective. International Migration Review, $44(1): 227-264$.

di Lego, V., Turra, C. M., and Cesar, C. (2017). Mortality selection among adults in brazil: The survival advantage of air force officers. Demographic Research, 37:1339-1350.

Elo, I. T. and Preston, S. H. (1996). Educational differentials in mortality: United states, 1979-1985. Social Science $\&$ Medicine, 42(1):47-57.

Folger, J. K. and Nam, C. B. (1964). Educational trends from census data. Demography, 1(1):247-57.

Garcia, R. A. (2013). Estimativas dos emigrantes internacionais do brasil entre 1995 e 2000: uma aplicação do método das razões intercensitárias de sobrevivência. Revista Brasileira de Estudos de População, 30(1):99-123.

Gomes, M. M. F. and Turra, C. M. (2009). The number of centenarians in brazil: Indirect estimates based on death certificates. Demographic Research, 20:495-502.

Gustavus, S. O. and Nam, C. B. (1968). Estimates of the "true" educational distribution of the adult population of the united states from 1910 to 1960. Demography, 5(1):410-421.

IBGE (2003). Censo demográfico 2000-resultados da pesquisa de avaliação da cobertura da coleta. Technical report, Instituto Brasileiro de Geografi a e Estatística - Ministerio do Planejamento, Orcamento e Gestao. 
IBGE (2004). Tendências demográficas : Uma análise dos resultados da amostra do censo demográfico 2000. Technical report, Instituto Brasileiro de Geografi a e Estatística - Ministerio do Planejamento, Orcamento e Gestao.

IPUMS-I (2019). Integrated public use microdata series, international: Version 7.2[dataset]. Minesota Population Center, Minneapolis.

Johnson-Greene, D., Dehring, M., Adams, K. M., Miller, T., Arora, S., Beylin, A., and Brandon, R. (1997). Accuracy of self-reported educational attainment among diverse patient populations: a preliminary investigation. Archives of clinical neuropsychology : the official journal of the National Academy of Neuropsychologists, 12:635-643.

Kane, T., Rouse, C. E., and Staiger, D. (1999). Estimating returns to schooling when schooling is misreported. Technical report, NBER Working Paper No. 7235.

KC, S., Barakatand, B., Goujon, A., Skirbekk, V., and Lutz, W. (2010). Projection of populations by level of educational attainment, age, and sex for 120 countries for 2005-2050. Demographic Research, 22:383-472.

Koch, E., Romero, T., Manríquez, L., Paredes, M., Ortúzar, E., Taylor, A., Román, C., Kirschbaum, A., and Díaz, C. (2007). Desigualdad educacional y socioeconómica como determinante de mortalidad en chile: análisis de sobrevida en la cohorte del proyecto san francisco. Revista médica de Chile, 135(11).

Lerch, M., Spoerri, A., Jasilionis, D., and Fernandèz, F. V. (2017). On the plausibility of socioeconomic mortality estimates derived from linked data: a demographic approach. Population Health Metrics, 15(1).

Lewis, J. R. (1986). International labour migration and uneven regional development in labour exporting countries. Tijdschrift voor Economische en Sociale Geografie, 77(1):27-41.

Lima, E. E. C. and Queiroz, B. L. (2014). Evolution of the deaths registry system in brazil: associations with changes in the mortality profile, under-registration of death counts, and ill-defined causes of death. Cadernos de Saúde Pública, 30(8):1721-1730.

Lutz, W., Butz, W. P., and KC, S. (2014). World Population and Human Capital in the Twenty-First Century. Oxford University Press.

Lutz, W. and KC, S. (2011). Global human capital: Integrating education and population. Science, $333(6042): 587-592$.

Lutz, W. and Kebede, E. (2018). Education and health: Redrawing the preston curve. Population and Development Review, 44(2):343-361.

Mackenbach, J. P., Kunst, A. E., Groenhof, F., Borgan, J. K., Costa, G., Faggiano, F., Józan, P., Leinsalu, M., Martikainen, P., Rychtarikova, J., and Valkonen, T. (1999). Socioeconomic inequalities in mortality among women and among men: an international study. American Journal of Public Health, 89(12):1800-1806.

Nepomuceno, M. R. and Turra, C. M. (2019). The population of centenarians in brazil: historical estimates from 1900 to 2000. Technical report, MPIDR Working Paper WP-2019-015.

Paes, N. A. (2007). Qualidade das estatísticas de óbitos por causas desconhecidas dos estados brasileiros. Revista de Saúde Pública, 41(3):436-445. 
Paes, N. A. and Albuquerque, M. E. E. (1999). Avaliação da qualidade dos dados populacionais e cobertura dos registros de óbitos para as regiões brasileiras. Revista de Saúde Pública, 33(1):33-43.

Potter, J. E., Schmertmann, C. P., Assunção, R. M., and Cavenaghi, S. M. (2010). Mapping the timing, pace, and scale of the fertility transition in Brazil. Population and Development Review, 36(2):283-307.

Preston, S. and Taubman, P. (1994). Demography of Aging, chapter Socioeconomic differences in adult mortality and health status, pages 279-318. National Academy Press.

Rentería, E. and Turra, C. M. (2009). Measuring educational differences in mortality among women living in highly unequal societies with defective data: the case of Brazil. Technical Report 348, Textos para Discussão Cedeplar-UFMG - Universidade Federal de Minas Gerais.

Rigotti, J. I. R. and Cerqueira, C. A. (2004). Introdução á demografia da educação, chapter Variáveis de educação dos censos demográficos brasileiros de 1960 a 2000, pages 71-88. Associação Brasileira de Estudos Populacionais.

Rios-Neto, E. L. G., de Meireles Guimarães, R. R., Pimenta, P. S. F., and de Azevedo Moraes, T. (2010). Análise da evolução de indicadores educacionais no brasil:1981 a 2008. Technical report, Texto para discussão - Universidade Federal de Minas Gerais.

Rios-Neto, E. L. G., Miranda-Ribeiro, A., and Miranda-Ribeiro, P. (2018). Fertility differentials by education in Brazil: From the conclusion of fertility to the onset of postponement transition. Population and Development Review, 44(3):489-517.

Rosero-Bixby, L. and Dow, W. H. (2009). Surprising SES gradients in mortality, health, and biomarkers in a latin american population of adults. The Journals of Gerontology Series B: Psychological Sciences and Social Sciences, 64B(1):105-117.

Rostron, B., Boies, J., and Arias, E. (2010). Education reporting and classification on death certificates in the united states. Technical report, National Center for Health Statistics Vital and Health Statistics.

Shkolnikov, V. M., Jasilionis, D., Andreev, E. M., Jdanov, D. A., Stankuniene, V., and Ambrozaitiene, D. (2007). Linked versus unlinked estimates of mortality and length of life by education and marital status: Evidence from the first record linkage study in lithuania. Social Science $\&$ Medicine, 64(7):1392-1406.

Singh, S. and Casterline, J. (1985). Reproductive change in developing countries: insights from the World Fertility Survey, chapter The socio-economic determinants of fertility, pages 199-222. Oxford University Press.

Smith-Greenaway, E. and Yeatman, S. (2019). Unrealized educational expectations and mental health: Evidence from a low-income country. Social Forces.

Sorlie, P. D. and Johnson, N. J. (1996). Validity of education information on the death certificate. Epidemiology, $7(4): 437-439$.

Turra, C. M. (2012). Os limites do corpo: A longevidade em uma perspectiva demográfica. Revista da UFMG, 19(1):156-181.

Turra, C. M., Renteria, E., and Guimarães, R. (2016). The effect of changes in educational composition on adult female mortality in Brazil. Research on Aging, 38(3):283-298. 
Turra, C. M., Ribeiro, M. M., and de Xavier Pinto, C. C. (2018). Padrões de mortalidade por escolaridade no brasil: evidências a partir do sistema de informação sobre mortalidade. In Anais do XXI Encontro Nacional de Estudos Populacionais.

United Nations (2015). The millennium development goals report. Technical report, United Nations.

United Nations (2016). The sustainable development goals report. Technical report, United Nations.

United Nations (2017). World population prospects 2017. Department of Economic and Social Affairs, Population Division.

Zhu, H. and Xie, Y. (2007). Socioeconomic differentials in mortality among the oldest old in china. Research on Aging, 29(2):125-143. 